\title{
Henneguya (Cnidaria: Myxosporea: Myxobolidae) infections \\ of cultured barramundi, Lates calcarifer (Perciformes: Latidae) \\ in an estuarine wetlands system of Malaysia: description \\ of Henneguya setiuensis n. sp., Henneguya voronini n. sp. and Henneguya calcarifer $\mathrm{n}$. sp.
}

\author{
Muhammad Hafiz Borkhanuddin ${ }^{1}$ - Gábor Cech ${ }^{2}$ - Kálmán Molnár ${ }^{2}$ • Faizah Shaharom-Harrison ${ }^{3}$. \\ Tran Nguyen Duy Khoa ${ }^{5}$ - Muhammad Arif Samshuri ${ }^{1}$ • Suhairi Mazelan ${ }^{4}$ - Stephen D. Atkinson ${ }^{6}$ • Csaba Székely ${ }^{2}$ (D)
}

Received: 28 November 2018 / Accepted: 5 November 2019 / Published online: 25 November 2019

(C) The Author(s) 2019

\begin{abstract}
Examination of 35 barramundi (Lates calcarifer) from aquaculture cages in Setiu Wetland, Malaysia, revealed a single fish infected with three Henneguya spp. (Cnidaria: Myxosporea). Characterization of the infections using tissue tropism, myxospore morphology and morphometry and 18S rDNA sequencing supported description of three new species: Henneguya setiuensis n. sp., Henneguya voronini n. sp. and H. calcarifer n. sp. Myxospores of all three species had typical Henneguya morphology, with two polar capsules in the plane of the suture, an oval spore body, smooth valve cell surfaces, and two caudal appendages. Spores were morphometrically similar, and many dimensions overlapped, but H. voronini n. sp. had shorter caudal appendages compared with $H$. calcarifer n. sp. and $H$. setiuensis n. sp. Gross tissue tropism distinguished the muscle parasite $H$. calcarifer $\mathrm{n}$. sp. from gill parasites $H$. setiuensis n. sp. and $H$. voronini n. sp.; and these latter two species were further separable by fine-scale location of developing plasmodia, which were intralamellar for $H$. setiuensis n. sp. and basal to the filaments for $H$. voronini $\mathrm{n}$. sp. small subunit ribosomal DNA sequences distinguished all three species: the two gill species $H$. setiuensis n. sp. and $H$ voronini n. sp. were only $88 \%$ similar (over 1708 bp), whereas the muscle species $H$. calcarifer n. sp. was most similar to $H$. voronini n. sp. (98\% over 1696 bp). None of the three novel species was more than $90 \%$ similar to any known myxosporean sequence in GenBank. Low infection prevalence of these myxosporeans and lack of obvious tissue pathology from developing plasmodia suggested none of these parasites are currently a problem for barramundi culture in Setiu Wetland; however additional surveys of fish, particularly at different times of the year, would be informative for better risk assessment.
\end{abstract}

Keywords Cnidaria $\cdot$ Henneguya $\cdot$ Setiu Wetlands $\cdot$ Barramundi $\cdot$ South China Sea

Section Editor: Astrid Holzer

Csaba Székely

szekely.csaba@agrar.mta.hu

1 Faculty of Science \& Marine Environment, Universiti Malaysia Terengganu, 21030 Kuala Nerus, Malaysia

2 Institute for Veterinary Medical Research, Centre for Agricultural Research, Hungarian Academy of Sciences, POB 18, Budapest H-1581, Hungary

3 Faculty of Fisheries \& Food Science, Universiti Malaysia Terengganu, 21030 Kuala Nerus, Malaysia
4 Institute of Tropical Aquaculture \& Fisheries Research (AKUATROP), Universiti Malaysia Terengganu, 21030 Kuala Nerus, Malaysia

5 Department of Coastal Aquaculture, Can Tho University, Ninh Kieu District, Can Tho City, Viet Nam

6 Department of Microbiology, Oregon State University, Corvallis, Oregon 97330, USA 


\section{Introduction}

Myxosporeans (Cnidaria: Myxosporea) are common, diverse parasites of marine and freshwater fishes (Lom and Dyková 2006). The genus Henneguya Thélohan, 1892, in family Myxobolidae, is the third most speciose myxosporean genus after Myxidium and Myxobolus, with > 200 Henneguya species described (Eiras 2002; Eiras and Adriano 2012; Székely et al. 2018). While most Henneguya species do not cause overt disease in their hosts, a few are economically important pathogens. Infections can cause mortalities in fish populations if parasites replicate to high intensities on the gills and cause respiratory insufficiency, especially in juvenile fish (Haaparanta et al. 1994; Whitaker et al. 2005). For example, H. ictaluri Pote, Hanson et Shivaji, 2000, causes proliferative gill disease in cultured channel catfish (Ictalurus punctatus Rafinesque) with up to 50\% mortality (Bowser and Conroy 1985; Bosworth et al. 2003), and H. lateolabracis Yokoyama, Kawakami, Yasuda et Tanaka, 2003, is the causative agent of fatal cardiac henneguyosis in cultured Japanese seabass (Lateolabrax spp.) (Pote et al. 2000; Yokoyama et al. 2003). Henneguya infection in the muscle can reduce the quality and marketability of the fish (Patashnik and Groninger 1964; Boyce et al. 1985), while other Henneguya species, for example, H. testicularis and $H$. oviperda, which are commonly found in the gonads of farmed fish, may affect reproductive health (Sitjá-Bobadilla 2009; Sokolov et al. 2019). Henneguya prevalence of infection can reach $75-100 \%$, with an intensity of up to 8,000 cysts in one fish (Nie 1996; Fomena and Bouix 1996). Whether intense or not, exposure of the fish host to other stressors can exacerbate disease effects of the parasite, for example, under stressful or aggregated conditions, mortality of $95-100 \%$ has been reported in farm-reared channel catfish (Bowser and Conroy 1985; Minchew 1972).

Previous studies have demonstrated that Henneguya spp. are the most common myxosporean parasites in non-cyprinid fishes in Southeast Asia (Molnár et al. 2006a, 2006b; Székely et al. 2009a, 2009b). From Malaysia, the few known Henneguya species are from freshwater host species and/or habitats (Shariff 1982; Molnár et al. 2006a, 2006b; Székely et al. 2009a, 2009b). Six species are described from noncyprinid fishes in Malaysia: H. shariffi Molnár, Székely, Mohamed and Shaharom-Harrison, 2006, in Pangasianodon hyphopthalmus Sauvage (Pangasidae: Siluriformes); H. mystusia Sarkar, 1985, in Hemibagrus nemurus Valenciennes (Bagridae: Siluriformes); H. basifilamentalis Molnár, Székely, Mohamed and Shaharom-Harrison, 2006, in H. nemurus; H. shaharini Shariff 1982, in Oxyeleotris marmorata (Bleeker) (Eleotridae: Perciformes); and H. hemibagri Tchang et Ma, 1993, in H. nemurus, all from the municipality of Kuala Terengganu, and H. daoudi Székely, Shaharom-Harrison, Mohamed and Molnár, 2009 in Trichopodus trichopterus (Pallas) (Osphronemidae:
Perciformes), from Machang municipality. This research on the biodiversity of Henneguya spp. in freshwater habitats contrasts sharply with the paucity of information on these parasites from marine or estuarine fishes (Eiras 2002; Dyková et al. 2011).

Fishes of the genus Lates include species that are economically important such as Lates calcarifer (Barramundi) or Lates niloticus (Nile perch), which have been cultured globally as popular food fish (Tantikitti et al. 2005; Biswas et al. 2010; Aloo et al. 2017). Barramundi is cultured primarily in sea cages near river mouths or estuaries and harvested throughout the year in the Indo-pacific region (Boonyaratpalin 1997; Tantikitti et al. 2005; Biswas et al. 2010). Despite their importance, very little myxosporean research has been conducted on these fishes. Only one Henneguya species is known from barramundi, $H$. latesi Tripathi 1952, from India, together with several other myxosporeans: Myxidium calcariferi Chakravarty, 1943, Myxidium procerum var. calcariferi Chakravarty, 1943, and Myxobolus calcariferum Basu and Haldar, 2003 (Tripathi 1952; Eiras et al. 2005; Eiras et al. 2011).

Henneguya has never been documented formally in cultured barramundi in Setiu Wetland, Terengganu, Malaysia, despite recurring observations (2009-2012) of spores in gills, but never from the muscle (Shaharom-Harrison pers. comm.). These observations prompted us to formally identify the species and determine if the parasite/s were causing any pathology in the barramundi, which are cultured at high densities with other important fish species like groupers (Epinephelus sp.). We conducted a limited survey of myxosporean parasites in cultured barramundi and identified three new Henneguya species: $H$. setiuensis $\mathrm{n}$. sp. and $H$. voronini $\mathrm{n}$. sp. from different locations in the gills and $H$. calcarifer $n$. sp. from the skeletal muscle.

\section{Materials and methods}

\section{Host and parasite samples}

Cultured barramundi, Lates calcarifer $(\mathrm{n}=35$; length $15-30$ $\mathrm{cm})$, were sampled from estuarine net cages from Setiu Wetland, Malaysia $\left(5^{\circ} 40^{\prime} 53.30^{\prime \prime} \mathrm{N}, 102^{\circ} 42^{\prime} 43.93\right.$ ”E). Specimens were transported live to the Institute of Tropical Aquaculture (AKUATROP), University Malaysia Terengganu (UMT), in March 2013, and maintained in an aerated fish tank. Within 5 days of collection, fish were sedated using clove oil and killed by a cervical cut, according to institutional animal treatment protocols. Fish were necropsied and surveyed for myxosporean parasites with a Leica EZ4 stereomicroscope and a Leica DM750 compound microscope. We examined the body surface, oral cavity, gills, heart, gall bladder, kidney and skeletal muscle for overt myxosporean 
pseudocysts (plasmodia). When suspected myxosporean plasmodia were found, they were excised using fine forceps and then ruptured in a drop of phosphate-buffered saline (PBS) and the contents examined in wet mount preparations. Parasites were examined and photographed using a Nikon Model Eclipse 80i advanced light microscope. Spores were checked for the presence of an iodinophilous vacuole after adding a drop of Lugol's iodine solution. At least 2 dimensions (length, width or thickness) were measured from 30 or more spores from each plasmodium, according to the guidelines of Lom and Arthur (1989), with the exception that we use the more structurally accurate term "polar tubule" instead of "polar filament". Spores from individual plasmodia were preserved in $80 \%$ ethanol for subsequent molecular analysis. For histological examination, tissue samples from infected organs containing mature plasmodia were fixed in Bouin's solution, embedded in paraffin wax, sectioned at 5-6 $\mu \mathrm{m}$ and stained with haematoxylin and eosin.

\section{Molecular and phylogenetic analyses}

At the IVMR CAR HAS, Hungary, DNA was extracted from the ethanol fixed spores using a DNeasy tissue kit (animal tissue protocol; Qiagen, Germany) according to the manufacturer's instructions. Two rounds of PCR were performed: round 1 with universal eukaryotic small subunit ribosomal DNA (18S rDNA) primers ERIB1 and ERIB10 and fully nested round 2 with primers Myx1F and SphR (Table 1). First-round amplifications were performed in $25 \mu \mathrm{l}$ reactions that comprised $2 \mu \mathrm{l}$ extracted DNA ( $\sim 0.2 \mu \mathrm{g}), 0.2 \mathrm{mM}$ of each dNTP (MBI Fermentas), $0.5 \mu \mathrm{M}$ each of the forward and reverse primers, $2.5 \mu \mathrm{l} 10 \times$ Taq buffer (MBI Fermentas), $2 \mathrm{U}$ Taq polymerase (MBI Fermentas) and $15 \mu \mathrm{l}$ of water. Thermal cycling comprised initial denaturation at $95^{\circ} \mathrm{C}$ for $3 \mathrm{~min}$, followed by 35 cycles of $1 \mathrm{~min}$ at $95{ }^{\circ} \mathrm{C}, 1 \mathrm{~min}$ at $55^{\circ} \mathrm{C}$ and $2 \mathrm{~min}$ at $72{ }^{\circ} \mathrm{C}$, completed with terminal extension for $7 \mathrm{~min}$ at $72{ }^{\circ} \mathrm{C}$ and then resting at $4{ }^{\circ} \mathrm{C}$.
Second-round PCR was conducted in $50 \mu$ l, which consisted of $1 \mu \mathrm{l}$ amplified DNA $(\sim 0.5 \mu \mathrm{g}), 0.2 \mathrm{mM}$ of each dNTP (MBI Fermentas), $0.5 \mu \mathrm{M}$ each of the forward and reverse primers, $5 \mu 10 \times$ Taq buffer (MBI Fermentas), 2 U Taq polymerase (MBI Fermentas) and $33 \mu \mathrm{l}$ of water. Amplification conditions in the second round were $95{ }^{\circ} \mathrm{C}$ for $3 \mathrm{~min}$, followed by 35 cycles of $95{ }^{\circ} \mathrm{C}$ for $50 \mathrm{~s}, 50{ }^{\circ} \mathrm{C}$ for $50 \mathrm{~s}$ and $72{ }^{\circ} \mathrm{C}$ for $1 \mathrm{~min} 40 \mathrm{~s}$, with terminal extension of $72{ }^{\circ} \mathrm{C}$ for $10 \mathrm{~min}$, and then rest at $4{ }^{\circ} \mathrm{C}$. All PCRs were performed in a PTC-200 thermocycler (MJ Research).

Amplified DNA was purified with EZ-10 Spin Column PCR Purification Kit (Bio Basic Inc., USA) and then sequenced in both directions using an ABI BigDye Terminator v3.1 Cycle Sequencing Kit with an ABI 3100 Genetic Analyser (IVMR, HAS). Initial short ( $800 \mathrm{bp}$ ) sequences inspired development of new Henneguya-specific sequencing primers HMF1, HMF2, HMR1 and HMR2 (Table 1).

BLAST searches were conducted to determine affinities to other myxosporeans in NCBI GenBank, and we selected the $3318 \mathrm{~S}$ rDNA sequences that had above $80 \%$ similarity to our three novel Henneguya species. These sequences were aligned using Clustal W (Thompson et al. 1994). Alignments were corrected manually in MEGA X (Kumar et al. 2018). The dataset was tested using MEGA $\mathrm{X}$ for the nucleotide substitution model of best fit as indicated by the Akaike Information Criterion (AIC). Phylogenetic relationships were inferred using the Maximum Likelihood (ML) method with the GTR + G + I substitution model and bootstrapping with 1000 replicates. Chloromyxum cyprini (AY604198) was chosen as the outgroup, as this represents one of the most primitive lineages of the myxosporean group that includes Henneguya spp. Genetic distances were determined using the $p$-distance model matrix in MEGA X.

Table 1 Primers used for PCR and sequencing

\begin{tabular}{llll}
\hline Primer & Sequence & Application & Reference \\
\hline ERIB1 & 5'-ACCTGGTTGATCCTGCCAG-3' & 1st round PCR & Barta (1997) \\
ERIB10 & 5'-CTTCCGCAGGTTCACCTACGG-3' & 1st round PCR & Barta (1997) \\
Myx1F & 5'-GTG AGA CTG CGG ACG GCT CAG-3' & 2nd round PCR & Hallett and Diamant (2001) \\
SphR & 5'-GTT ACC ATT GTA GCG CGC GT-3' & 2nd round PCR and sequencing & Eszterbauer and Székely (2004) \\
MC5 & 5'-CCT GAG AAA CGG CTA CCA CAT CCA-3' & Sequencing & Molnár et al. (2002) \\
MC3 & 5'-GAT TAG CCT GAC AGA TCA CTC CAC A-3' & Sequencing & Molnár et al. (2002) \\
HMF1 & 5'-GAT CTG GTG ATG AGT GGT GCA T-3' & Sequencing & Present study \\
HMF2 & 5'-GAG TTG TTC AAT GCT CGG GAT-3' & Sequencing & Present study \\
HMR1 & 5'-GGC CAT CCT TAC GCG CAA TTA -3' & Sequencing & Present study \\
HMR2 & 5'-GCA ACG TCG AAC CAA AGC GAT-3' & Sequencing & Present study \\
\hline
\end{tabular}




\section{Scanning electron microscopic (SEM)}

Plasmodia of Henneguya voronini $\mathrm{n}$. sp. were compressed and ruptured onto $25 \times 40 \mathrm{~mm}$ glass slides, fixed in $2.5 \%$ glutaraldehyde, then washed several times in $0.1 \mathrm{M}$ sodium cacodylate buffer and postfixed in cold $1 \%(\mathrm{w} / \mathrm{v})$ osmium tetroxide. Fixed tissue was then dehydrated in an alcohol series of $35 \%$ to $100 \%$ for 10 - to 15 -min each step, and then critical point dried in carbon dioxide (Baltac CPD 030). The glass slide containing the dried specimens was cut into smaller pieces, mounted onto aluminium stubs with double-sided tape and then sputter-coated with gold (Jeol JFC 1600). The specimens were examined in a Jeol SEM (Model JSM 6360LA).

\section{Results}

Thirty-five barramundi were examined, and myxosporean infections were found in only a single fish. Plasmodia were found in two different organs, the gills and the muscle. Plasmodia in the gills occurred in two well-differentiated locations: spherical plasmodia 50-70 $\mu \mathrm{m}$ in diameter developed intra-lamellarly, whereas ellipsoidal plasmodia 250-300 × $130-150 \mu \mathrm{m}$ were located basi-filamentally between gill filaments. A third type of plasmodium, which was ovoid and 300-400 $\mu \mathrm{m}$ long, was found within the skeletal muscle. All three types of plasmodia contained mature myxospores, which were morphologically similar, with compact, ellipsoidal spore bodies of typical Henneguya morphology, with two polar capsules in the plane of the suture, smooth surfaced valve cells, with caudal appendages that extended about four times longer than the spore body. Morphometrics (Table 2) overlapped among myxospores from the three different tissue locations. Our diagnosis of three different species was based on morphological comparisons with existing records, specific tissue site of development and 18S rDNA sequence data (see below for taxonomic summaries).

\section{Henneguya setiuensis $\mathbf{n} . \mathbf{s p}$.}

Type host: barramundi, Lates calcarifer (Bloch 1790).

Site of infection: Within gill lamellae.

Locality: Setiu Wetlands, Terengganu, Malaysia.

Prevalence of infection: $2.8 \%$ (1/35).

Vouchers: Digital images of syntype spores and histological sections deposited in the parasitological collection of the Zoological Department, Hungarian Natural History Museum, Budapest, collection no. HNHM-71892. The 18S rDNA sequence was deposited in GenBank under accession number MH743111.

Etymology: The species is named after the collection location, Setiu Wetlands, Malaysia.
Description of spores: Spores symmetric, with two equal caudal appendages, fusiform sporebody, two equal-sized pyriform polar capsules (Fig. 1). Spore wall thin $(0.3-0.4 \mu \mathrm{m}$ ), smooth and composed of two equal valves. Apical end of spore body blunt, caudal end tapered and extends into the caudal appendages. Fresh myxospores 36-41 $\mu \mathrm{m}$ long, spore length $8.9 \pm 0.4(8.3-9.5) \mu \mathrm{m}$, width $5.9 \pm 0.3(5.8-6.0) \mu \mathrm{m}$ and thickness $4.1 \pm 0.1(4.1-4.2) \mu \mathrm{m}$. Two polar capsules, pyriform, blunt at the posterior end and taper anteriorly, length $3.3 \pm 0.2(3.1-3.5) \mu \mathrm{m}$ and width $2.1 \pm 0.1(2.0-2.2) \mu \mathrm{m}$. Polar tubules coiled in 6 turns perpendicular to the long axis of the polar capsules. Sporoplasm binucleate with a small iodinophilous vacuole. Caudal appendages straight, tapering, $30.5 \pm 1.6(28.0-32.0) \mu \mathrm{m}$. Plasmodia spherical, diameter 50$75 \mu \mathrm{m}$.

Remarks: We identified H. setiuensis n. sp. as a new species based on host, site of development (intra-lamellar in gills), morphology and morphometrics. The spores were most similar morphometrically and by tissue tropism (gill) to a previously described species $H$. latesi Tripathi 1952, from barramundi in India; however, the description of this earlier species has limited informative characters for comparison of spore measurements, and no $18 \mathrm{~S}$ rDNA sequence data (Table 2). From the limited data available for comparison, H. setiuensis n. sp. was distinct in spore body shape (rounder vs oval), total length $(36-41 \mu \mathrm{m}$ vs 26-36 $\mu \mathrm{m})$ and spore thickness $(4.1 \mu \mathrm{m}$ vs $5.4 \mu \mathrm{m})$. Determination of whether $H$. latesi represents a taxon distinct from any that we observed in Malaysian barramundi would require rediscovery of parasite material from the type locality in India, with molecular and fine-scale tissue tropism observations. Compared with Henneguya spp. known from Lates species hosts, $H$. setiuensis n. sp. was unique in most dimensions (Table 2) and had the smallest plasmodia; however molecular data and specific tissue site of infection are not available for these other species for more precise comparison. H. setiuensis $\mathrm{n}$. sp. was morphometrically similar to the other two species found in the same fish in the current study, except spore width, polar capsule width and plasmodium size, but distinguishable based on fine-scale tissue tropism and DNA sequence.

Molecular analysis: Our consensus $18 \mathrm{~S}$ rDNA sequence of 1708 bp was shown by BLAST search to be most similar to other Henneguya species in GenBank, but all $<89 \%$. Pairwise comparison showed $H$. setiuensis $\mathrm{n}$. sp. to be no more than $91 \%$ similar to the other Henneguya species found in the same fish: $89.9 \%$, p-distance 0.101 with $H$. calcarifer $\mathrm{n}$. sp.; $90.1 \%$, p-distance 0.099 with $H$. voronini $\mathrm{n}$. sp.

Histology: Plasmodia observed in different parts of the gill filaments, inside the multilayered epithelium between lamellae (Fig. 4a-b ). Only local damage of the lamellae was observed, with no gross pathology of the gill filaments. 
Henneguya voronini $\mathbf{n} . \mathbf{s p}$.

Type host: barramundi, Lates calcarifer (Bloch 1790).

Site of infection: Base of the gill filament.

Type locality: Setiu Wetlands, Terengganu, Malaysia.

Prevalence of infection: $2.8 \%$ (1/35).

Type material: Digital images of syntype spores and histological sections were deposited in the parasitological collection of the Zoological Department, Hungarian Natural History Museum, Budapest, collection no. HNHM-71893. The $18 \mathrm{~S}$ rDNA sequence was deposited in GenBank under accession number MH743110.

Etymology: The species is named in honour of V. A. Voronin, an eminent Russian fish parasitologist.

Description of spores: Myxospores symmetric, with two equal caudal appendages and equal-sized polar capsules (Fig. 2). Spore wall thin (0.3-0.4 $\mu \mathrm{m})$, smooth and composed of 2 equal valves. Apical end of spore body blunt, the caudal end tapers and extends into the caudal appendages. Total length 35-39 $\mu \mathrm{m}$, length of spore $9.9 \pm 0.3(9.5-10.3) \mu \mathrm{m}$ and width $5.9 \pm 0.3(5.8-6.0) \mu \mathrm{m}$; thickness could not be measured as no spores were observed in sutural plane. Polar capsules pear shaped, blunt at the posterior end and tapered anteriorly, length $3.7 \pm 0.2(3.5-4.0) \mu \mathrm{m}$ and width $2.1 \pm 0.1$ $(2.0-2.2) \mu \mathrm{m}$. Polar tubules coiled in 6 turns perpendicular to the long axis of the polar capsules. Sporoplasm binucleate, with a small iodinophilous vacuole. Caudal appendages straight, tapering, length $27.2 \pm 1.4(25.0-29.0) \mu \mathrm{m}$, about 4 times as long as the spore body. Plasmodium ellipsoidal 250 $300 \mu \mathrm{m} \times 130-150 \mu \mathrm{m}$.

Remarks: Myxospores of $H$. voronini n. sp. could not be distinguished morphometrically using most measurements with the two other species observed in the host. Both $H$. voronini $\mathrm{n}$. $\mathrm{sp}$. and $H$. setiuensis $\mathrm{n}$. sp. were found in the gills but the specific tissue locality differed: the large ellipsoidal plasmodia (up to $300 \mu \mathrm{m}$ ) of $H$. voronini $\mathrm{n}$. sp. were localized to the cartilaginous base of the gill filaments, while the smaller spherical plasmodia of $H$. setiuensis $\mathrm{n}$. sp. (up to $75 \mu \mathrm{m})$ developed between lamellae of the gill filaments. Considering Henneguya spp. from other Lates species, spores of $H$. voronini $\mathrm{n}$. sp. could be differentiated in at least two dimensions (Table 2).

Molecular analysis: 1696 bp 18S rDNA were sequenced, including the primers. A BLAST search indicated that highest sequence similarities were to other Henneguya species in GenBank, but all $<90 \%$. Pairwise analysis showed $H$. voronini $\mathrm{n}$. sp. was molecularly very similar to H. calcarifer n. sp. $(97.7 \% ; 1658 / 1969$ bp; $p$-distance 0.013), described from the same fish (below).

Histology: Ellipsoidal plasmodia were located in the cartilaginous gill arch between gill filaments (Fig. 4c). We suspect that development began in the multilayered connective tissue covering the gill arch and then a large part of the plasmodium 
Fig. 1 Henneguya setiuensis $n$. sp. (a-b) Line drawings of mature myxospores in frontal view showing polar capsules with coiled polar tubules. (c) Fresh, unstained myxospores in frontal (arrow) and sutural (*) views, with divergent caudal appendages
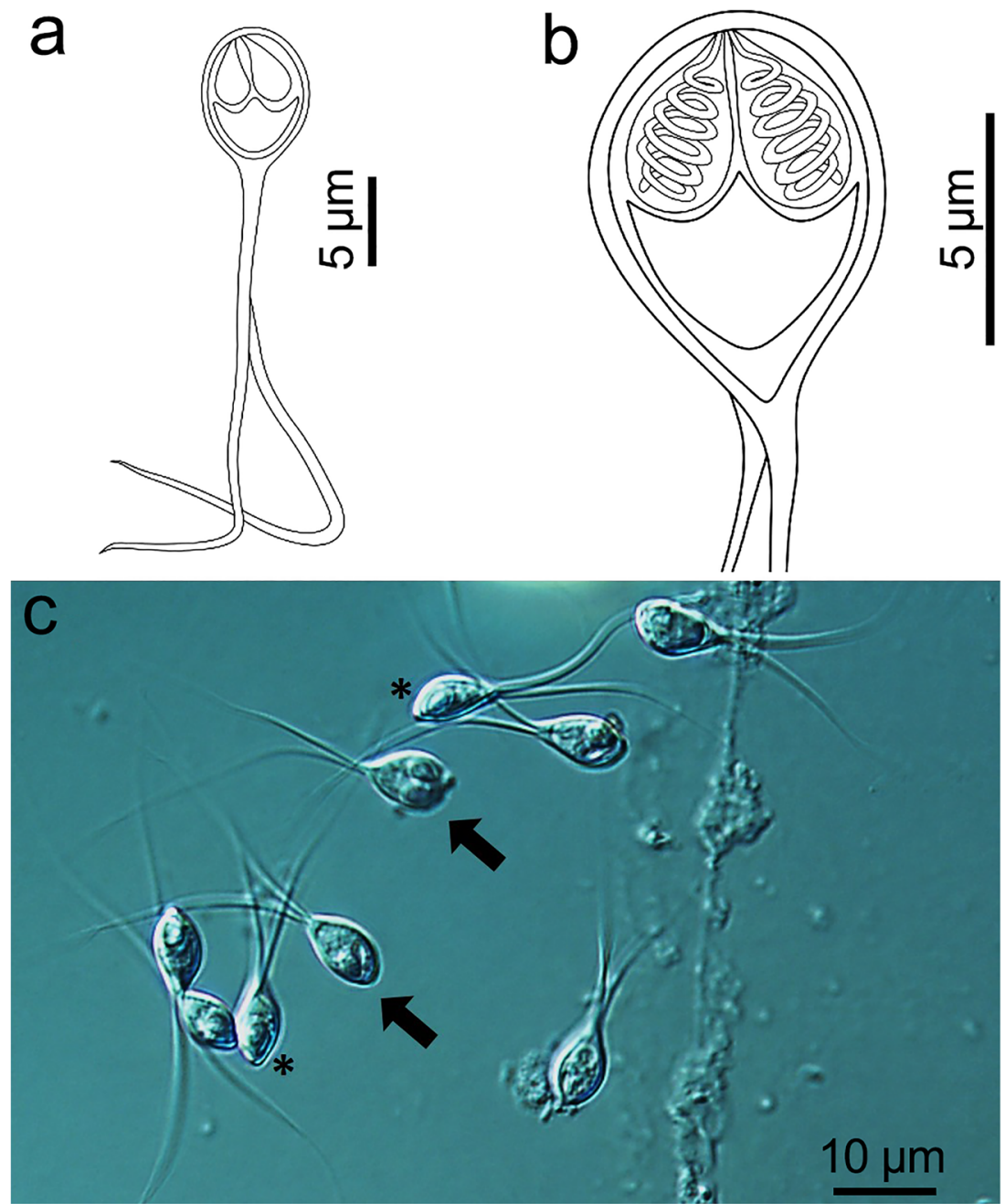

moved into the gill filaments and was covered by a multilayered epithelium as it matured.

Microscopy: SEM revealed that the valve cell surfaces were smooth, which is a morphological feature typical of genus Henneguya.

\section{Henneguya calcarifer $\mathbf{n} . \mathbf{s p}$.}

Type host: barramundi, Lates calcarifer (Bloch 1790).

Site of infection: Skeletal muscle.

Type locality: Setiu Wetlands, Terengganu, Malaysia.

Prevalence of infection: $2.8 \%$ (1/35).

Type material: Digital images of syntype spores were deposited in the parasitological collection of the Zoological Department, Hungarian Natural History Museum, Budapest, collection no. HNHM-71894. The 18S rDNA sequence was deposited in GenBank under accession number MH743109

Etymology: The species is named after the host.

Description of spores: Fig. 3. Myxospores symmetric, with two equal caudal appendages, and equal-sized polar capsules. Spore wall 0.3-0.4 $\mu \mathrm{m}$, smooth and composed of two equal valves. Apical end of spore body blunt, the caudal end tapers and extends into the caudal appendages, total length 34-45 $\mu \mathrm{m}$. Spore length $9.4 \pm 0.6$ (8.3-10.0) $\mu \mathrm{m}$, width $5.2 \pm 0.3(4.8-5.5) \mu \mathrm{m}$ and thickness $3.8 \pm 0.1(3.7-4.0) \mu \mathrm{m}$. Two polar capsules pear shaped, blunt at the posterior end and taper anteriorly, length $3.4 \pm 0.2(3.1-3.7) \mu \mathrm{m}$ and width $1.4 \pm 0.2$ (1.1-1.7) $\mu \mathrm{m}$. Polar tubules coiled in 6 turns perpendicular to the long axis of the capsule. Sporoplasm binucleate with a small iodinophilous vacuole. Caudal appendages straight, tapering, length $30.9 \pm 3.0(28.0-35.0) \mu \mathrm{m}$, $\sim 4$ times longer than the spore body. Plasmodia spherical $300 \times 400 \mu \mathrm{m}$.

Remarks: H. calcarifer n. sp. resembles morphologically and morphometrically both $H$. setiuensis n. sp. and $H$. voronini $\mathrm{n}$. sp. (Table 2) but has different tissue site of development (muscles not gill). This is the first muscle-infecting Henneguya described from Lates calcarifer and is relatively distinct from the only other 
Fig. 2 Henneguya voronini n. sp. $(\mathbf{a}-\mathbf{b})$ Line drawings of mature myxospores in frontal view showing polar capsules with coiled polar tubules. (c) Fresh, unstained myxospores in frontal view showing the two pyriform polar capsules. (d) Scanning electron microscope image of the spores showing simple, smooth valve cell surfaces, each contiguous with a caudal process; features typical of the genus
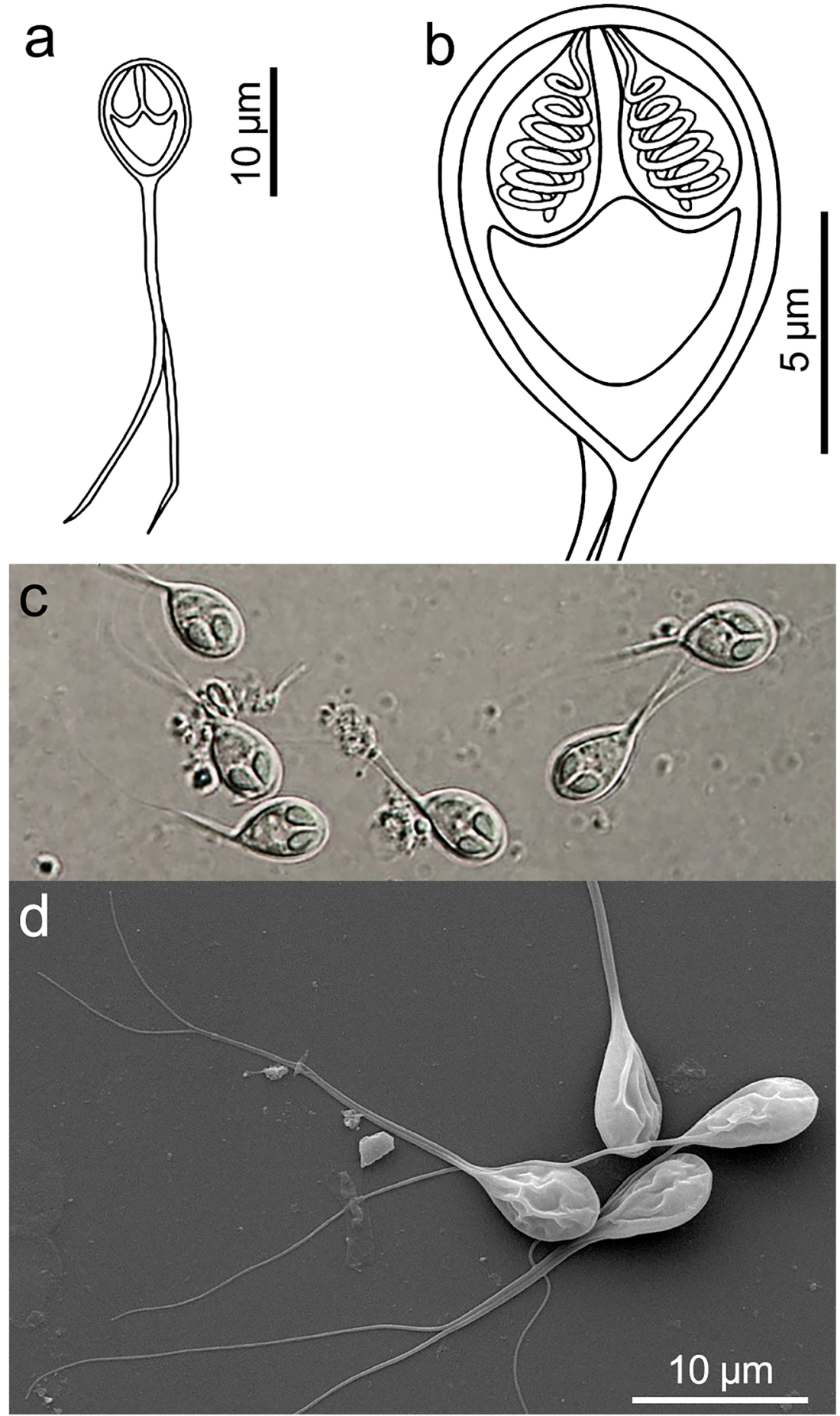

species from a Lates congener: $H$. ghaffari from muscle and gills of L. niloticus in Egypt (Table 2).

Molecular analysis: 1696 bp 18S rDNA were sequenced. A BLAST search indicated that the most similar species were other Henneguya species, but all $<89 \%$. Pairwise analysis showed $H$. calcarifer n. sp. was molecularly very similar (97.7\% over 1696 bp) with $H$. voronini n. sp., described from the same fish (above).
Histology: Low intensity of parasite plasmodia in the host skeletal muscle meant no plasmodia were visible in histological sections.

\section{Phylogenetic analysis}

Phylogenetic analyses of 43 myxosporean sequences revealed a topology that showed correlation of myxosporeans 
Fig. 3 Henneguya calcarifer $\mathrm{n}$. sp. (a-b) Line drawings of mature myxospores in frontal view showing polar capsules with coiled polar tubules. (c) Unstained, compressed plasmodium, densely packed with mature myxospores

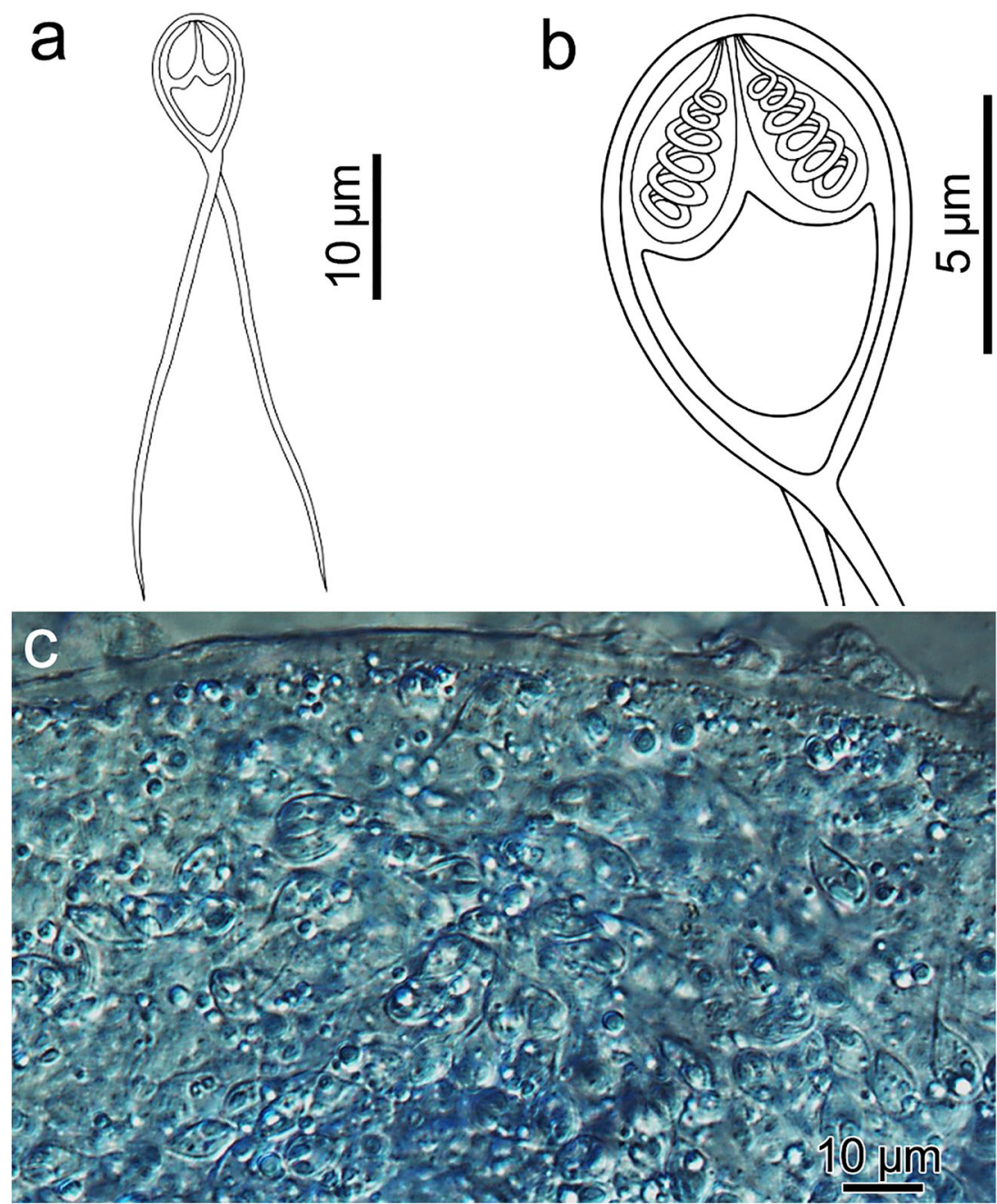

clustering with host order, with Henneguya spp. that infect Perciformes clustering into three distinct clades. The three species described herein cluster together within a subclade that includes another species that infect Perciformes (Fig. 5).

\section{Discussion}

Henneguya is histozoic myxosporean parasite of freshwater and marine fishes and one of the most species-rich genus of myxosporeans with more than 200 species described (Lom and Dyková 2006; Eiras 2002; Eiras and Adriano 2012). We used characters of specific host, tissue, myxospore morphology and $18 \mathrm{~S}$ rDNA sequences to describe three Henneguya species in barramundi, Lates calcarifer, from the east coast of Peninsula Malaysia. Henneguya setiuensis n. sp. and $H$. voronini $\mathrm{n}$. sp. developed between gill lamellae and at the base of the gill filaments, respectively, while $H$. calcarifer $\mathrm{n}$. sp. developed in skeletal muscle from the flank of the fish. Discovery of the Henneguya infections in gills was not unexpected, as this organ is a common site of myxobolid infections; however, H. calcarifer n. sp. is the first myxosporean with a preference for muscle in a species of Lates. Muscle tropism of Henneguya species is less common than gills, being a character of 8 of some 180 species, including only 1 from a host in the Asian region: $H$. ophicephali Chakravarty, 1939, in Ophiocephalus punctatus from India (Eiras 2002; Eiras and Adriano 2012).

Henneguya has the distinctive morphological character of two caudal appendages, which distinguishes it from the other genera of the family Myxobolidae. However, molecular (SSU rDNA) evidence shows that genus Henneguya is polyphyletic, and this does not support the hypothesis that the presence of caudal appendages is a valid character for distinguishing species of Henneguya from Myxobolus (see comprehensive analysis in Liu et al. 2019). While we acknowledge the weak support for Henneguya as a distinct genus, formal taxonomic revision of genera within Myxobolidae is still lacking and is outside the scope of the present study. Accordingly we described the three novel species herein as Henneguya, based on the historical morphological character-based definition, augmented with DNA data. 


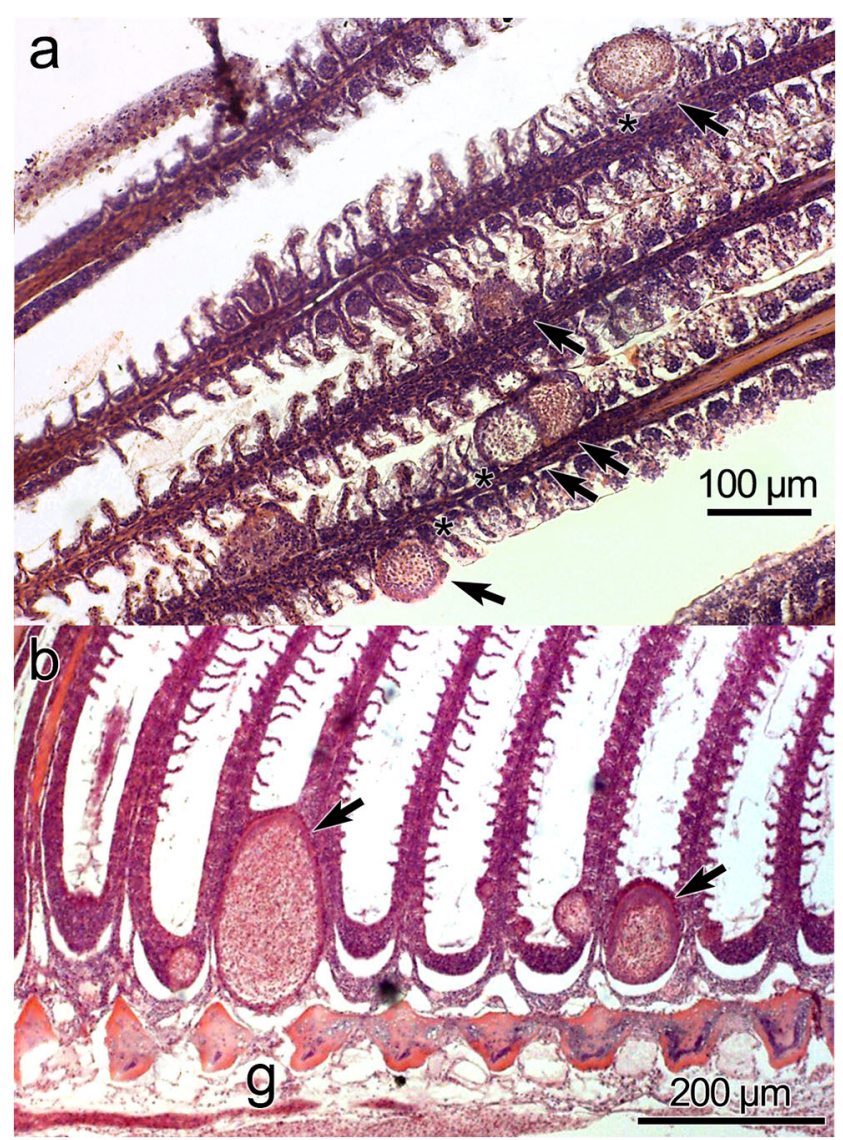

Fig. 4 Histological sections of gill filaments from Lates calcarifer infected by plasmodia of $H$. setiuensis n. sp. and $H$. voronini $\mathrm{n}$. sp. (a) Plasmodia of $\mathrm{H}$. setiuensis n. sp. (arrows) producing compression and damage to the lamellae (*). (b) Development of plasmodia of $H$. voronini $\mathrm{n}$. sp. (arrows) in the sub-epithelial layer at the base of the filament. Note that the plasmodia also impinge into the gill arch (g)

Our PCR approach for genetically characterizing the parasites was based on previous work to amplify DNA from another Malaysian Henneguya species, $H$. daoudi, in which its $18 \mathrm{~S}$ rDNA was sequenced using "freshwater" myxosporean primers SphF-SphR, MC3-MC5 and MB5r-MB5f (Székely et al. 2009a). Although we were able to amplify $\sim 800 \mathrm{bp}$ fragments using SpHR, MC3 and MC5, these did not overlap sufficiently to construct contigs. Accordingly, we used our sequence information from $H$. calcarifer $\mathrm{n}$. sp. to design new barramundiHenneguya-specific primer pairs HMF-HMF2 and HMR1HMR2, to give sufficient coverage to assemble contigs of 1696-1708 bp, including terminal primers MYX1f and SphR.

Henneguya species can cause disease and mortality in farmed fish species, for example, $H$. exilis in catfish (Current and Janovy 1977) and H. piaractus in pacu (Martins et al. 1997). Our study of parasites of $L$. calcarifer was to assess the baseline occurrence of myxosporeans and any associated pathology in this important aquaculture species in Malaysia. We observed infection in only $1 / 35$ fish (2.8\%), but this individual was positive for all three Henneguya species. This was lower than prevalences of other Henneguya infections in Lates spp.: H. mandouri $32 / 40,80 \%$; H. ghaffari $65 / 188,34.6 \%$; H. latesi 6/20, 30\%; and H. massii 3/67 (4.4\%) (Tripathi 1952; Ali 1999; Kostoïngue et al. 2001; Rabie et al. 2009). In addition to low prevalence, the single fish that we observed with the infections did not have any observable pathology associated with the parasites. This is consistent with the Henneguya infections from congeneric hosts, with none of these reported to cause henneguyosis (Tripathi 1952; Ali 1999; Kostoïngue et al. 2001; Rabie et al. 2009).

Correlation between particular myxosporean species and tissue tropism in the vertebrate host is well-established (e.g. Molnár 1994), particularly in species of Myxobolidae, with fine-scale tissue preferences being observed in the gills (Molnár 2002; Eszterbauer 2004). Alternatively, many myxobolids and myxosporean species in general tend to cluster according to the family/order of the fish host, with this character being useful to distinguish genetically closely related species (e.g. Ferguson et al. 2008; Carriero et al. 2013; Vieira et al. 2017; Naldoni et al. 2018; Holzer et al. 2018; Liu et al. 2019). In the present study, our phylogenetic analysis showed that the three novel Henneguya species formed a well-supported sub-clade of perciform-infecting myxobolids, which included Henneguya sp. 3 PBS-2015 (KP030761), from gills of Lates niloticus from Lake Turkana, Kenya, and Henneguya daoudi (EU643625), from gills of another perciform fish, Trichogaster trichopterus from Malaysia (Fig. 5). The nearest sister clade included Myxobolus neurophilus (KF588564) and Henneguya chaudhuryi (KT279402), both of which infect perciform fish: Perca flavescens (yellow perch) and Channa punctata (spotted snakehead), respectively. The analysis thus revealed a stronger correlation between all three novel Henneguya spp. and their host, rather than the specific tissue in which they developed a pattern consistent across multiple groups of Myxobolidae as demonstrated previously (Liu et al. 2019).

Our taxonomic diagnosis incorporated consideration of whether either gill-infecting Henneguya species had already been described. Specifically, we considered their similarity with the only Henneguya known from gills (and mouth) of L. calcarifer: H. latesi Tripathi 1952, in barramundi from India. The description of that parasite is limited to host, tissue and morphometry (no DNA, no micrographs; Tripathi 1952). The taxon shares host and one of the two reported tissues (gills) with $H$. setiuensis $\mathrm{n}$. sp. and $H$. voronini $\mathrm{n}$. sp. but differs in most myxospore dimensions. We concluded that there was insufficient evidence to unambiguously identify either of our Malaysian gillinfecting species as $H$. latesi. Furthermore, given that we observed two genetically distinct Henneguya species within the gills, it is possible that the original description of $H$. latesi for "gills and mouth" could actually represent two distinct species. Determination of whether $H$. latesi represents a single taxon, distinct from any that we observed in Malaysian barramundi, would require redescription $H$. latesi from the type locality in India, with molecular and fine-scale tissue tropism observations. 


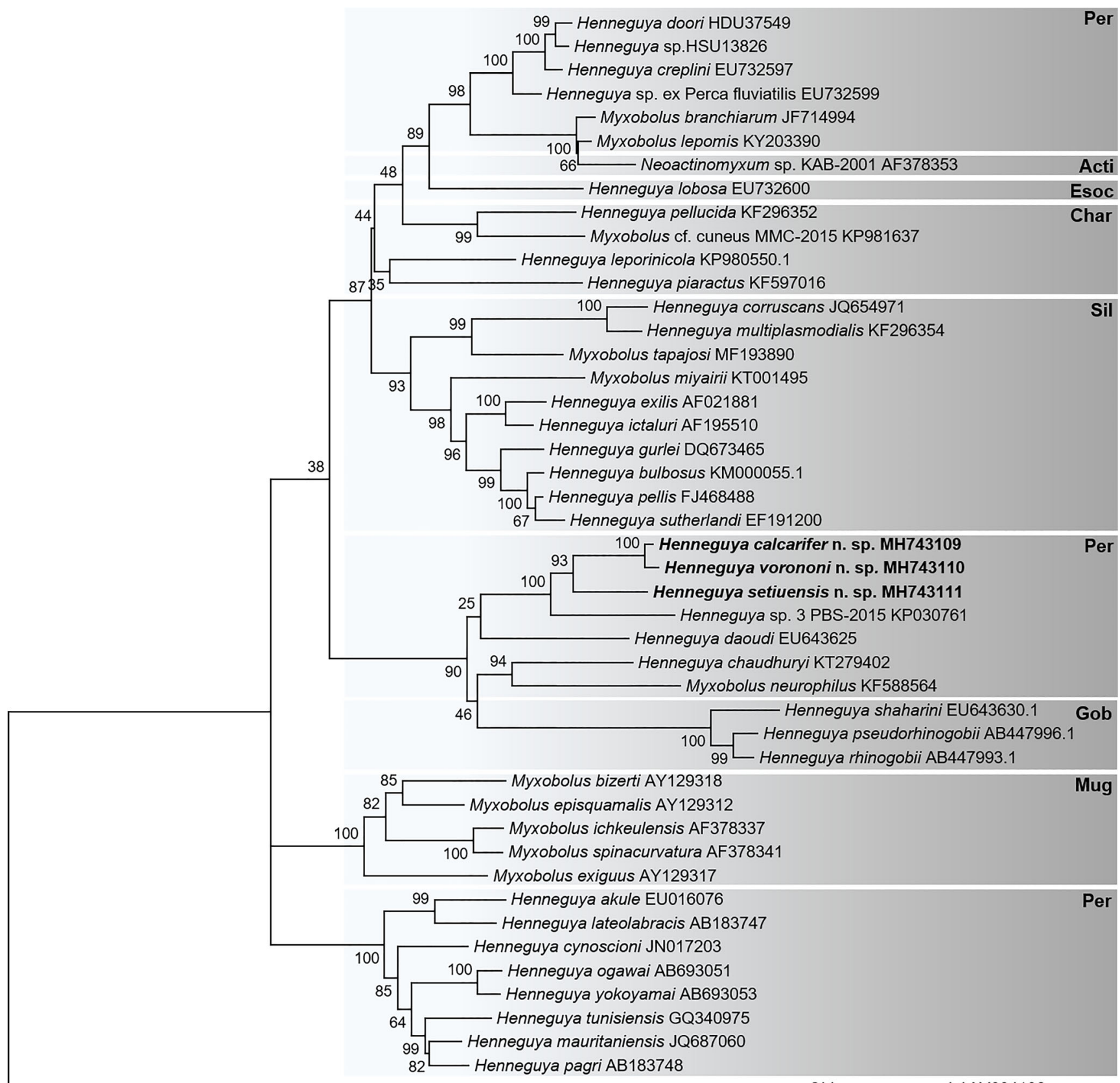

Chloromyxum cyprini AY604198

0.1

Fig. 5 Phylogenetic tree generated by maximum likelihood analysis of $18 \mathrm{~S}$ ribosomal DNA sequences of Henneguya species from perciform hosts and other closely related myxosporean species identified by BLAST; GenBank accession numbers shown after the species name, including the three novel data in bold (H. setiuensis n. sp., $H$. voronini

Based on our limited sampling, we demonstrated the presence of at least three Henneguya species that parasitize barramundi in Malaysia. In our target population, these parasites occurred only at low prevalence and intensity, and without overt pathology. The health effects of any of these Henneguya species either singly or combined are unknown in populations of fish under conditions of stress or exposed n. sp. and H. calcarifer n. sp.). Numbers at nodes indicate the bootstrap confidence values (ML). Taxonomic orders of the fish hosts are shown at right: Char Characiformes, Sil Siluriformes, Esoc Esociformes, Mug Mugiliformes, Gob Gobiiformes, Per Perciformes and Acti Actinospores. Chloromyxum cyprini was used as an outgroup

to other health impacts from intense aquaculture, where Henneguya-related disease could emerge. Future work should concentrate on surveys from additional cultured fishes (both barramundi and grouper) from this region, under different stress levels and rearing conditions, to determine what other myxosporean species might be present and might be causing disease impacts. 
Acknowledgements We are grateful to AKUATROP officers for their excellent support during the field work and their help in the collection of fish specimens. We are grateful for the SEM work of Kartini Mohamed. We would also like to thank the staff of Biodiversity Laboratory (FSME) for their assistance in dissecting the fish and to the anonymous reviewers for their helpful suggestions that improved this article.

We acknowledge the Malaysian Ministry of Higher Education (MOHE) for the Niche Research Grant Scheme NRGS/2015/53131/33 granted to MHB, and the GINOP 2.3.2-15-2016-00004 project Establishing the sustainable angling-aimed management of Lake Balaton' for support provided to SzCs.

Funding Information Open access funding provided by MTA Centre for Agricultural Research (MTA ATK).

Open Access This article is distributed under the terms of the Creative Commons Attribution 4.0 International License (http:// creativecommons.org/licenses/by/4.0/), which permits unrestricted use, distribution, and reproduction in any medium, provided you give appropriate credit to the original author(s) and the source, provide a link to the Creative Commons license, and indicate if changes were made.

\section{References}

Ali MA (1999) Henneguya ghaffari sp. n. (Myxozoa: Myxosporea), infecting the Nile perch Lates niloticus (Teleostei: Centropomidae). Dis Aquat Org 28:225-230

Aloo PA, Njiru J, Balirwa JS, Nyamweya CS (2017) Impacts of Nile Perch, Lates niloticus, introduction on the ecology, economy and conservation of Lake Victoria, East Africa. Lakes Reserv Res Manag 22(4):320-333

Barta JR (1997) Investigating phylogenetic relationships within the Apicomplexa using sequence data: the search for homology. Methods 13(2):81-88

Biswas G, Thirunavukkarasu AR, Sundaray JK, Kailasam M (2010) Optimization of feeding frequency of Asian seabass (Lates calcarifer) fry reared in net cages under brackish water environment. Aquaculture 305(1-4):26-31

Boonyaratpalin M (1997) Nutrient requirements of marine food fish cultured in Southeast Asia. Aquaculture 151(1-4):283-313

Bosworth BG, Wise DJ, Terhune JS, Wolters WR (2003) Family and genetic group effects for resistance to proliferative gill disease in channel catfish, blue catfish and channel catfish $\mathrm{x}$ blue catfish backcross hybrids. Aquac Res 34(7):569-573

Bowser PR, Conroy D (1985) Histopathology associated of gill lesions with Henneguya in channel catfish. J Wildl Dis 21:177-179

Boyce NP, Kabata Z, Margolis L (1985) Investigations of the distribution, detection, and biology of Henneguya salminicola (Protozoa, Myxozoa), a parasite of the flesh of Pacific salmon. Can Tech Rep Fish Aquat Sci No 1405

Carriero MM, Adriano EA, Silva MRM, Ceccarelli PS, Maia AAM (2013) Molecular phylogeny of the Myxobolus and Henneguya genera with several new South American species. PLoS ONE 8(9)

Current WL, Janovy JJ (1977) Sporogenesis in Henneguya exilis infecting the channel catfish: an ultrastructural study. Protistol 13:157167

Dyková I, de Buron I, Roumillat WA, Fiala I (2011) Henneguya cynoscioni sp. n. (Myxosporea: Bivalvulida), an agent of severe cardiac lesions in the spotted seatrout, Cynoscion nebulosus (Teleostei: Sciaenidae). Folia Parasitol 58(3):169-177
Eiras JC (2002) Synopsis of the species of the genus Henneguya Thélohan, 1892 Myxozoa: Myxosporea: Myxobolidae. Syst Parasitol 52(1):43-54

Eiras JC, Adriano EA (2012) A checklist of new species of Henneguya Thélohan, 1892 (Myxozoa: Myxosporea, Myxobolidae) described between 2002 and 2012. Syst Parasitol 83:95-104

Eiras JC, Molnár K, Lu YS (2005) Synopsis of the species of Myxobolus Bütschli, 1882 (Myxozoa: Myxosporea: Myxobolidae). Syst Parasitol 61:1-46

Eiras JC, Saraiva A, Cruz CF, Santos MJ, Fiala I (2011) Synopsis of the species of Myxidium Bütschli, 1882 (Myxozoa: Myxosporea: Bivalvulida). Syst Parasitol 80:81-116

Eszterbauer E (2004) Genetic relationship among gill-infecting Myxobolus species (Myxosporea) of cyprinids: molecular evidence of importance of tissue-specificity. Dis Aquat Org 58:35-40

Eszterbauer E, Székely C (2004) Molecular phylogeny of the kidneyparasitic Sphaerospora renicola from common carp (Cyprinus carpio) and Sphaerospora sp. from goldfish (Carassius auratus auratus). Acta Vet Hung 52(4):469-478

Ferguson JA, Atkinson SD, Whipps CM, Kent ML (2008) Molecular and morphological analysis of Myxobolus spp. of salmonid fishes with the description of a new Myxobolus species. J Parasitol 94:13221334

Fomena A, Bouix G (1996) New species of Henneguya Thélohan, 1892 (Myxozoa: Myxosporea) parasites of freshwater fishes in Cameroon. J Afr Zool 110:413-423

Fomena A, Bouix G (2000) Henneguya mbakaouensis sp. nov., Myxobolus nounensis sp. nov. and M. hydrocyni Kostoingue \& Toguebaye, 1994, Myxosporea (Myxozoa) parasites of Centropomidae, Cichlidae and Characidae (Teleosts) of the Sanaga Basin in Cameroon (Central Africa). Parasite 7:209-214

Haaparanta A, Valtonen ET, Hoffman RW (1994) Pathogenicity and seasonal occurrence of Henneguya creplini (Protozoa, Myxosporea) on the gills of perch Perca fluviatilis in central Finland. Dis Aquat Org 20:15-22

Hallett SL, Diamant A (2001) Ultrastructure and small-subunit ribosomal DNA sequence of Henneguya lesteri n. sp.. (Myxosporea), a parasite of sand whiting Sillago analis (Sillaginidae) from the coast of Queensland, Australia. Dis Aquat Org 46(3):197-212

Holzer AS, Bartošová-Sojková P, Born-Torrijos A, Lövy A, Hartigan A, Fiala I (2018) The joint evolution of the Myxozoa and their alternate hosts: A cnidarian recipe for success and vast biodiversity. Mol Ecol 27:1651-1666

Kostoïngue B, Diebakate C, Faye N, Toguebaye BS (2001) Presence of myxosporidea (Myxozoa: Myxosporea) of the genus Henneguya Thélohan, 1892 in freshwater fishes from Chad (Central Africa). Acta Protozool 40:117-123

Kumar S, Stecher G, Li M, Knyaz C, Tamura K (2018) MEGA X: Molecular evolutionary genetics analysis across computing platforms. Mol Biol Evol 35(6):1547-1549

Liu Y, Lövy A, Gu Z, Fiala I (2019) Phylogeny of Myxobolidae (Myxozoa) and the evolution of myxospore appendages in the Myxobolus clade. Int J Parasitol 49:523-530

Lom J, Arthur JR (1989) A guideline for the preparation of species descriptions in Myxosporea. J Fish Dis 12:151-156

Lom J, Dyková I (2006) Myxozoan genera : definition and notes on taxonomy, life-cycle terminology and pathogenic species. Folia Parasitol 53:1-36

Martins ML, Souza VN, Moraes FR, Moraes JRE, Costa AJ, Rocha UF (1997) Pathology and behavioral effects associated with Henneguya sp. (Myxozoa: Myxobolidae) infections of captive pacu Piaractus mesopotamicus in Brazil. J World Aquacult Soc 28:297-300

Minchew CD (1972) Identification and frequency of occurrence of four forms of Henneguya found in channel catfish. Proceedings of the 26th Annual Conference of the Southeastern Fish and Game Commissions 
Molnár K (1994) Comments on the host, organ and tissue specificity of fish myxosporeans and on the types of their intrapiscine development. Parasitol Hung 27:5-20

Molnár K (2002) Site preference of fish myxosporeans in the gill. Dis Aquat Org 48:197-207

Molnár K, Eszterbauer E, Székely C, Dán Á, Harrach B (2002) Morphological and molecular biological studies on intramuscular Myxobolus spp. of cyprinid fish. J Fish Dis 25(11):643-652

Molnár K, Székely C, Mohamed K, Shaharom-Harrison F (2006a) Myxozoan pathogens in cultured Malaysian fishes. I. Myxozoan infection of the sutchi catfish. Dis Aquat Org 68:209-218

Molnár K, Székely C, Mohamed K, Shaharom-Harrison F (2006b) Myxozoan pathogens in cultured Malaysian fishes. II. Myxozoan infections of redtail catfish Hemibagrus nemurus in freshwater cage cultures. Dis Aquat Org 68:219-226

Naldoni J, Maia AAM, Correa LL, Silva MRM, Adriano EA (2018) Two new myxosporean species parasite of Phractocephalus hemioliopterus from the Brazilian Amazon: morphology, ultrastructure and SSU-rDNA sequencing. Dis Aquat Org 128:37-49

Nie P (1996) Co-occurrence and microhabitat of Ancyrocephalus mogurndae (Monogenea) and Henneguya weishanensis (Myxosporea) on gills of the mandarin fish, Siniperca chuatsi. Folia Parasitol 43:272-276

Pote LM, Hanson LA, Shivaji R (2000) Small subunit ribosomal RNA sequences link the cause of proliferative gill disease in channel catfish to Henneguya n. sp.. (Myxozoa: Myxosporea). J Aquat Anim Health 12(3):230-240

Rabie SA, Mohammed NI, Hussein AN, Hussein NM (2009) The infection of freshwater fishes with three species of Henneguya in Qena. Upper Egypt Egypt Acad J Biol Sci 1:11-19

Shariff M (1982) Henneguya shaharini sp. nov. (Protozoa: Myxozoa), a parasite of marble goby, Oxyeleotris marmoratus (Bleeker). J Fish Dis 5:37-45

Sitjá-Bobadilla A (2009) Can myxosporean parasites compromise fish and amphibian reproduction? P Roy Soc B-Biol Sci 276:2861-2870

Sokolov SG, Lebedeva DI, Murzina SA, Parshukov AN, Bystrova KA, Ieshko EP (2019) Morphology and phylogeny of Henneguya oviperda infecting oocytes of Esox lucius, with description of parasite-induced histopathology. Dis Aquat Org 133(2):91-98
Székely C, Shaharom-Harrison F, Cech G, Mohamed K, Molnár K (2009a) Myxozoan pathogens of Malaysian fishes cultured in ponds and net-cages. Dis Aquat Org 83(1):49-57

Székely C, Shaharom-Harrison F, Cech G, Ostoros G, Molnár K (2009b) Myxozoan pathogens of fishes of the Tasik Kenyir Water Resevoir, Terengganu, Malaysia. Dis Aquat Org 83(1):37-48

Székely C, Borzák R, Molnár K (2018) Description of Henneguya jaczoi sp. n. (Myxosporea, Myxobolidae) from Perca fluviatilis (1.) (Pisces, Percidae) with some remarks on the systematics of Henneguya spp. of European fishes. Acta Vet Hung 66(3):426-443

Tantikitti C, Sangpong W, Chiavareesajja S (2005) Effects of defatted soybean protein levels on growth performance and nitrogen and phosphorus excretion in Asian seabass (Lates calcarifer). Aquaculture 248(1-4):41-50

Thompson JD, Higgins DG, Gibson TJ (1994) CLUSTAL W: improving the sensitivity of progressive multiple sequence alignment through sequence weighting, position-specific gap penalties and weight matrix choice. Nucleic Acids Res 22:4673-4680

Tripathi YR (1952) Studies on parasites of Indian fishes I. Protozoa: Myxosporidia together with a check list of parasitic protozoa described from Indian fishes. Rec. Indian Museum 50:63-88

Vieira DHMD, Alama-Bermejo G, Bartholomew JL, Abdallah VD, Azevedo RK (2017) Morphological and molecular description of Myxobolus batalhensis n. sp.. (Myxozoa, Myxosporea), a liver and ovary parasite of Salminus hilarii in Brazil. Parasitol Res 116:33033313

Whitaker JW, Pote LM, Hanson LA (2005) Assay to detect the actinospore and myxospore stages of proliferative gill disease in oligochaetes and pond water. N Am J Aquac 67:133-137

Yokoyama H, Kawakami H, Yasuda H, Tanaka S (2003) Henneguya lateolabracis (sp. n. Myxozoa: Myxosporea), the causative agent of cardiac henneguyosis in Chinese sea bass Lateolabrax sp. Fish Sci 69(6):1116-1120

Publisher's note Springer Nature remains neutral with regard to jurisdictional claims in published maps and institutional affiliations. 